\author{
Милан Игрутиновић
}

\title{
Мање од збира свих делова: глобални замах комунизма након Другог светског рата
}

\begin{abstract}
Санейак
У раду се даје преглед основних токова односа комунистичких партија и држава након Другог светског рата, у контексту почетка Хладног рата. Аутор обраћа посебну пажњу на тренд интегративног повезивања унутар два идеолошки супротстављена блока (капиталистички/Западни и комунистички/Источни), са нагласком на комунистички, и показује лимите сарадње партија и држава, различите и супротстављене амбиције. Аутор даје аргументе да су одређени билатерални проблеми у међусобним односима комунистичких партија и држава носили превагу над могућностима развоја интегративне сарадње, што је спречавало даљи развој комунистичког покрета на глобалном нивоу. За то он највише користи примере КП Кине и КП Југославије и њихов сукоб са СССР-ом, те проблеме идеолошке и спољнополитичке природе.
\end{abstract}

Кључне речи:

комунизам, КП Кине, НР Кина, СССР, Југославија, Хладни рат

\section{УВОД}

Осим пораза европског фашизма, нацизма и јапанског империјализма као очигледног резултата Другог светског рата, једна од његових последица била је и значајно увећање броја земаља у којима је успостављена комунистичка власт. До краја 1940-их осим Источне и Југоисточне Европе то је био процес који се одигравао и у Источној Азији. Велика улога Совјетског Савеза у ратној победи савезника тако није само осигурала 
преживљавање комунизма у једној земљи него и његово ширење и глобалну легитимизацију. Тај процес ће у истом периоду постати и један од главних градивних елемената Хладног рата.

У исто време, скала економске моћи је јасно показивала на америчку страну. Америчка економија је 1939. чинила око половине сабраних вредности друштвених производа економија Европе, СССР-а и Јапана; 1945. била је већа од њих заједно. Вашингтон је усмеравао нормативно уређење главних токова светске економије. Кроз Бретон-вудски договор 1944. године исцртане су послератне контуре међународног финансијског поретка и успостављене институције Међународног монетарног фонда и Светске банке (Међународне банке за обнову и развој). Поред спољнополитичких разлика, попут учвршћивања комунистичке власти у Источној Европи, тежњи да окупирана Немачка не постане поновна претња и жељом да се линија фронта сукоба са капитализмом држи што западније од совјетских граница, Москва ни из економских разлога није могла да се једноставно уклопи у амерички поредак. Питање политике цена, конвертибилности валуте, петогодишњих планова и непосредних практичних економских потреба обнове и развоја, гурали су Москву ван уских трансатлантских токова. Интеграција совјетске економије у главни ток глобалне економије под америчком доминацијом значила би нужно потпуну промену парадигме њене политичке економије. Ипак, Москва је веровала у делимичну интеграцију, у којој су совјетске сировине нужан елемент европске обнове, и раст спољнотрговинских односа на значајно виши ниво, и то ће бити основа врло ограничене економске размене током деценија Хладног рата у Европи. Промовисање тзв. Маршаловог плана - Европског програма обнове - од лета 1947. на основама слободнијих тржишта, попуштања међудржавних баријера привредним токовима и јачање социо-економских услова живота у Западној Европи, како би се сузбили мотиви јачања комунизма и на Западу, била је тачка разлаза: САД су га замислиле тако да га Совјети нису могли прихватити без напуштања нивоа контроле који су успоставили над појединим земљама Источне Европе, а Совјети нису хтели да прихвате амерички директни уплив у оно што су сматрали својом зоном интереса. Од 1948. године САД су увеле низ мера економских санкција према Совјетском Савезу, попут забране трговине војном опремом, високим технологијама, разним сировинама итд, у које су убрзо укључиле и своје европске савезнике, и те мере су постале стандардни модел односа према комунистичким земљама, уз неколико изузетака попут Југославије или Кине од 1970-их година. 
Поред тога, са Маршаловим планом је ефективно почело америчко подржавање низа пројеката економске и политичке интеграције Западне Европе. Главни ток интеграције започео је француско-британским споразумом у Денкерку (1947), којим је потврђена спремност на узајамну одбрану - формално од Немачке, али у суштини од Совјетског Савеза, који је наредне године проширен са три земље Бенелукса (Бриселски споразум, март 1948), а клаузула о заједничкој одбрани из тих споразума постала је камен темељац и Северноатлантског уговора (НАТО, април 1949) којим су се САД и формално везале за питање безбедности у Европи. Економско обједињавање започето је формирањем Европске заједнице за угаљ и челик (1951), која је послужила као основа за потоње стварање Европске економске заједнице (1957). Идеје о чвршћој политичкој и војној заједници, попут Европске одбрамбене заједнице (у плану и разматрању 1952-1954) нису добиле свој практичан политички израз, па и ако рачунамо Западноевропску унију (од 1954) као форму посве уске сарадње пре свега на пољу војно-технолошке сарадње, НАТО савез је остао камен међаш безбедносног оквира за земље Западне Европе.

\section{ОСНОВНЕ ФОРМЕ ИНТЕГРАЦИЈА КОМУНИСТИЧКИХ ДРЖАВА ЕВРОПЕ}

Делимичан одговор Москве на ове кораке обједињавања западних земаља уследио је у јесен 1947. године, стварањем Комунистичког информационог бироа (Коминформа). Совјетска економска моћ била је далеко слабија од америчке, а поврх тога Совјети још увек нису имали атомску бомбу, и диспаритет моћи је био још већи. Оно што је могло да се уради је да се цементирају добици на Истоку, те да се комунистичке партије у осталим земљама активније супротставе капитализму. Поред источно-европских комунистичких партија, владајућих у својим земљама, позване су и КП Француске и КП Италије, које је Москва сматрала довољно јаким да могу бити употребљиве у датом тренутку. Остале комунистичке партије нису зване; ни грчка, која се борбено ангажовала на северу земље у којој је још беснео грађански рат али није више спадала у совјетску сферу интереса, ни кинеска, ни низ мањих европских. Владајућим комунистичким партијама на Истоку Европе стављено је у задатак да убрзају транзицију друштава по совјетском моделу, да збију редове и изолују се од империјалистичког Запада (који их је са своје стране такође изоловао), док је комунистима у Италији и Француској препуштено 
да воде борбу на терену непријатеља, упорном идеолошком, пропагандном и изборном борбом.

Када су се представници КП Кине у Москви распитивали о свом чланству у Коминформу, Стаљин им је одговорио да је то било „апсолутно непотребно”, јер је „у Источној Европи буржоазија колаборирала са фашизмом и нацизмом и с пуним правом су јој требала бити одузета управљачка права и имовина, док у Кини током рата буржоазија није у битној мери сарађивала са јапанским окупаторима и није, бар у тој фази, требала бити мета КП Кине него је могла бити и савезник, по уходаним моделима народних фронтова као механизма формирања комунистичке власти". Као регионалну групацију Стаљин је замишљао Савез комунистичких партија Источне Азије, у којој би биле и КП Кине али и КП СССР, јер је СССР био и европска и азијска земља (Heinzig, 2015, pp. 228-229). Москва је желела да плете локализоване мреже комунистичких партија, којима би она била надређени координатор, а уз то и тумач интереса комунизма на светском нивоу.

У јануару 1949. године обједињавање комунистичких земаља Европе добило је свој економски израз кроз формирање Савета за узајамну економску помоћ (CEB). То је била круна тадашњих покушаја да се олакша трговина и сарадња међу поменутим земљама. Совјети су већ од 1947. иницирали талас међусобних пореских олакшица, смањење износа репарација на име ратне штете (од Мађарске и Румуније). Почетни резултати нису били занемарујући: повећање међусобне трговине је било рапидно, за два пута у периоду 1946-1950. и још скоро за два пута 1950-1955. Но, међусобна билатерална трговина је остала ендемска карактеристика CEB-а наредних деценија, ослоњена на искривљене ценовне политике и прилике које је она стварала (Sanchez-Sibony, 2014, pp. 69-70). СЕВ је географски остао везан за европско тло, упркос пријему у чланство посматрача појединих држава са осталих континената, попут Кубе (од 1972), Вијетнама (1978), НДР Кореје (1956), Анголе (1976) или Никарагве (1984), али не и НР Кине. Погоршавање билатералних односа Пекинга и Москве од краја 1950-их је било важније од суштине или само и декора комунистичког јединства.

\section{НР КИНА СТУПА НА СЦЕНУ}

Последња фаза двадесетдвогодишњег грађанског рата у Кини (19271949 ) вођена је од 1945. године, након окончања јапанске окупације над делом кинеске територије. У кинеској унутрашњој политици још увек је доминирао Куоминтанг, који је непосредно након рата држао контролу 
над великом већином градских центара у источном (условно - приморском) делу земље, док је КП Кина била ослоњена на руралне крајеве у центру земље и у Манџурији, на североистоку уз границу са СССР-ом. Успешном мобилизацијом сељаштва и умешним командовањем трупама Кинеске радничке и сељачке црвене армије, ефективно војног крила КП Кине, комунисти су успели да заузму низ великих градских центара до лета 1949. године. Тај низ победа натерао је покрет Куоминтанг да напусти главно тло Кине и да пресели тежиште својих активности на острва Тајван и Хаинан. Фактичка победа КП Кине у грађанском рату означила је стварање Народне Републике Кине, 1. октобра 1949. године, коју је вођа комуниста Мао Цедунг прогласио говором на пекиншком тргу Тјенанмен.

Однос НР Кине са СССР-ом одмах је добио прворазредни значај. С једне стране, искуство Совјета у извођењу револуције и трансформацији друштва према (неким) комунистичким узусима још је пре Другог светског рата постало готово неспорни извор инспирације, начелних и практичних решења за комунистичке револуционаре широм света. Са друге стране, комунисти на власти су у већој или мањој мери били ослоњени на своја искуства и локалне друштвене односе. Уосталом, раскид Москве и Београда од лета 1948. године експлицитно је показао супротстављеност различитих погледа на спољашње и унутрашње послове и отворио нове путеве у тумачењима „исправности” комунистичких прескрипција. Москва је тежила да очува своје интересе у североисточној Кини и да однос са НР Кином задржава у оквирима сопствених односа са западним земљама, док је Пекинг тежио да се додатно профилише на међународној сцени као нова комунистичка држава и да задржи конце у унутрашњој политици и просовјетско држање у спољној политици (Shen, 2020, pp. 123-132). До средине 1950. године две земље су склопиле Споразум о савезништву и пријатељству, и више секторских економских споразума, којима је обезбеђена совјетска техничка и менаџерска помоћ развоју Кине. До 1953. је следила и ефективна стаљинизација ${ }^{1}$ НР Кине у погледу форме развоја унутрашњих односа и корака које је КП Кине чинила у револуционарном преображају економије и друштва (Lüthi, 2010, pp. 28-29).

Систем који је подразумевао пресликавање совјетске економске политике из 1930-их година и у класичном смислу обухватао јавно-државно власништво над капиталом и средствима рада, командни систем планске економије без тржишних елемената, где је централизовани државни апарат планирао производњу и потрошњу, те давање развојних приоритета тешкој индустрији на уштрб пољопривреде и лаке индустрије. 
Поред тога, почетак Корејског рата (1950-1953) директно је увео обе земље у подухват обезбеђивања комунистичких позиција на Корејском полуострву, и у сукоб са САД и групом земаља окупљених око ње а под капом Уједињених нација. Пекинг је од дела својих трупа у близини корејског полуострва формирао Народну добровољачку армију која је директно укључена у борбу од јесени 1950. године, док је Москва слала војну технику, официрски кадар и ваздухопловне јединице под туђом - често и кинеском - заставом како би донекле маскирала своју инволвираност у сукоб. Рат је приведен крају лета 1953. године компромисним решењем и повлачењем границе која и данас дели две Кореје.

Стаљинова смрт (март 1953) је у Москви отворила питање персоналног и идеолошког наслеђа. Тежина унутрашњег притиска фактичке диктатуре Стаљина од краја 1920-их година гурала је наследнике ка практичном и формалном одрицању од таквог курса, а најснажнији израз је дошао кроз говор Никите Хрушчова, новог првог секретара КП СССР на 20. конгресу партије 1956. године, којим је отпочела ера „дестаљинизације" и „отопљавања" пре свега унутрашњих али делом и спољашњих послова земље. Колико је овај процес помогао у побољшању односа са Савезом комуниста Југославије, од Хрушчовљеве посете Београду маја 1955. године и политичке сагласности да Југославија може имати свој пут у социјализам, толико је, наредних година, закомпликовао односе са Пекингом и био једна од тачака расцепа између две највеће комунистичке земље. Мао Цедунг је донекле очекивао да ће критика Стаљина довести до већег уважавања кинеских ставова у билатералним односима, а зазирао је од тога што су капиталистичке земље активно користиле процес унутрашње критике стаљинизма да подрију комунизам у целини, што је пренео југословенској делегацији која је посетила Кину 1957. године (Westad, 1998, p. 19). Опет, партијској делегацији из Југославије је годину дана раније већ критиковао „великонационални и великопартијски шовинизам Стаљина”, жалећи се да га је овај третирао као „полу-Тита” у смислу да му прави проблеме (Shen, 2020, pp. 198-199). Временом, Пекинг је почео да доживљава совјетску политику као девијацију у односу на главни ток комунизма, и до почетка 1960-их је отворен јавни идеолошки спор. Са постепеним отварањем граничног питања између две земље и његовим неуспехом у његовом решавању у првој половини те деценије, сукоб се ширио и добио форму војне конфронтације 1968-69. године. Идеолошки одјеци сукоба ће наредних деценија бити видљиви у опредељењима, поступцима и приоритетима комунистичких покрета широм света. Поред тога, САД ће успети да побољшају своје односе са НР Кином и пажљиво помажу одржавању њене дистанце према СССР-у. 


\section{НР КИНА И КОМУНИСТИЧКА ЕВРОПА}

Победа КП Кине у грађанском рату је имала дијаметрално супротне ефекте у Западној и Источној Европи. Односи са комунистичким земљама Источне Европе су у грубим цртама пратили логику односа са Москвом - постојао је почетни ентузијазам, након чега је дошло до привремене стабилизације, па онда до ефективног опадања односа. Совјетско-кинески сукоб је отворио нешто већи простор источноевропским земљама да граде односе са Кином по својој мери, за шта је НСР Албанија била главни пример. Слично Пекингу, Тирана је Хрушчовљеву политику доживела као одступање од главног тока комунистичке идеологије. Поред тога, перманентни сукоб са Југославијом и постојање капиталистичке Грчке као другог суседа довели су до тога да власт Енвера Хоџе тражи нове правце спољнополитичке сарадње, и Кина се указала као згодан партнер, макар то био и „брак из погрешних очекивања” (Mehilli, 2017, p. 190).

У првим корацима економске обнове земље и изградње комунизма источноевропске земље су биле логичан партнер у контексту потраге за индустријским увозом, имајући у виду америчке санкције, као и за евентуалним подручјем за пласман сопствених пољопривредних производа. Сам Совјетски Савез је НР Кини до краја 1950-их пружио највећу техничку помоћ и трансфер технологије у кинеској историји, сасвим могуће и у светској историји (Zhang, Zhang, Yао, 2006). У том периоду су посеб́о били развијени кинески односи са Чехословачком и Пољском. Чехословачки комунисти су, желећи да очувају сарадњу која је била „дужа од Јангцеа и виша од Татри", покушавали да нађу средњи пут у сукобу СССР-а и Кине, очувају своје трговачке позиције и посебно извоз технолошких производа на бази дугорочних споразума (Adamec, 2019). Пољска и Кина су брзо развиле саобраћајне (поморске) везе, а заједничко државно предузеће, Чийолброк, формирано 1951. године, постоји и данас (Gnoinska, 2019). Оно је током Корејског рата посебно помогло кинеској спољној трговини да нешто слободније превози робу и одржава саобраћајне везе, будући да НР Кина није била ни чланица Уједињених нација, нити је имала развијене саобраћајне и уговорне односе.

Средином 1946. године представници Републике Кине у Берлину контактирали су југословенског представника да се распитају о могућности успостављања дипломатских односа. Годину дана касније Београд је успоставио дипломатске односе са Републиком Кином, уз благослове Москве. (Чавошки, 2006) Октобра 1949. брзо је призната нова влада Мао Цедунга, но Пекинг није одговорио на телеграм признања будући да је верно пратио партијску линију одређену избацивањем КП Југославије 
из Коминформа јуна 1948. године. Успостављање дипломатских односа извршено је тек јануара 1955. и ефективно је пратило совјетско-југословенско отопљавање.

Но, отопљавање односа је било кратког даха, будући да се убрзо распламсао идеолошки сукоб након усвајања новог програма СКЈ на 7. конгресу, који је додатно промовисао самоуправне друштвене принципе. Потом је СКЈ одбила да потпише декларацију 81 комунистичке партије, донету новембра 1960. на међународном састанку комунистичких и радничких партија, што је само појачало оптужбе да је она ревизионистичка и противна основним принципима марксизма. Идеолошки сукоб је остао основа билатералних односа до 1970-их, до полаганог отопљавања почетком те деценије током уласка НР Кине у Уједињене нације, и конкретно до путовања Јосипа Броза у НР Кину 1977. године.

Односи са земљама Западне Европе су фактички покидани успостављањем НР Кине, и до почетка 1960. били на занемарљиво ниском нивоу. Тек је сукоб са СССР-ом погурао Пекинг у смеру тражења нових економских могућности на том подручју, мада је Пекинг још придавао велики значај негативном наслеђу империјалним политикама неких од европских земаља. Томе је погодовала и чињеница да су прилике у Западној Европи тада већ биле и политички и економски стабилније, да је током 1960-их и кампање за пријем НР Кине у Уједињене нације била потребна подршка и две сталне чланице Савета безбедности (В. Британије и Француске). Растућа спољнополитичка самосталност Француске након завршетка Алжирског рата (1962) и релаксација односа са низом азијских земаља након напуштања Индокине као колонијалног поседа (1954) омогућили су известан рапрошман са НР Кином, јачање дипломатских, економских и културних односа у првој половини 1960-их година (Albers, 2016, pp. 13-34).

\section{ЗАКљУЧАК}

На крилима совјетске победе у Другом светског рату границе комунизма су проширене до средишње Европе. Убрзо потом, успешни подухват стварања НР Кине цементирао је добитке за глобални комунизам у источној Азији. Али, брзи почетак Хладног рата, економска надмоћ капиталистичког Запада, режими санкција које је он увео под вођством САД и симболични нивои трговине утицали су да се комунистичке земље повезују у изнуђеном и подређеном положају. То је комунистичком свету успоравало развој, у Европи посебно отворило политичке проблеме и на дуги рок нужно дерогирало легитимитет целог поретка. 
Улога СССР-а као „прве земље комунизма” је значила да је он био узор бројним комунистичким покретима, и да су искуства совјетског међуратног комунизма често била трасирана на локалне прилике, али не увек и не свуда. „Совјетизација” унутрашњих односа и институционалног поретка (велика централизација алокације ресурса, одређивање цена свим домаћим производима, присилна мобилизација рада на вишем нивоу итд.) дошла је најпре у оним земљама које су имале неку форму ратног ангажмана против некомунистичких суседа или и самих САД (НР Кина, ДНР Кореја, Северни Вијетнам, Куба итд) и које нису могле у потпуности да се посвете унутрашњем развоју. Сама Москва је више водила рачуна о својим државним интересима него о „светској револуцији", што није било зачуђујуће - треба се само подсетити нивоа разарања који је претрпљен током рата, а одједном су јој се отвориле одређене глобалне перспективе. Покушај Москве да управља комунистичким покретима показао се као фрагментаран, више опортун него стратешки планиран, ограничен ресурсима и често превазиђен догађајима на терену. Сукоб са социјалистичком Југославијом отворио је пукотину која никада више није зацељена; потоњи сукоб са НР Кином је био довољно велики да га је Америка у другој половини Хладног рата могла успешно експлоатисати.

Поред тога, убрзање процеса деколонизације од друге половине 1950-их указало је на нове хоризонте за комунизам. Бројни ослободилачки покрети који су своје земље успели довести до формално признате независности баштинили су барем неке идеје комунизма, већ у складу са локалним приликама и унутрашњим идеолошким развојем. Тиме су отворене могућности развоја сарадње које су европске комунистичке државе желеле да користе. То је, са друге стране, слабило темпо развоја унутар CEB-a - ширење могућности глобалне трговине водило је релативном смањењу међусобног значаја, будући да је структура економске интеграције била постављена на међузависности чланица. Процес деколонизације и проширење круга „пријатеља” са собом је донео и трошкове економске и политичке подршке и подигао цену одржања глобалног присуства за СССР.

Совјетски Савез самостално, а ни у концерту са другим комунистичким земљама, није успео да креира функционалан систем савезништава или широко прихваћених правила комунистичког света које би биле пандан капиталистичком свету (НАТО, ЕЕЗ, ММФ, Светска банка итд). Подређена економска позиција, превага непосредних над дугорочним интересима, идеолошко чистунство, биле су само неке од препрека на том потенцијалном путу. Тако су тензије и политички конфликти, попут оних на релацији Москва - Пекинг или Москва - Београд, били упечатљива 
карактеристика односа комунистичких земаља и снажна детерминанта Хладног рата.

\section{ЛИТЕРАТУРА}

1. Adamec, J. (2019). 'Our friendship is longer than the river Yangtze and higher than the Tatra Mountains: Sino-Czechoslovak Trade in the 1950s. In: Schaufelbuehl, J. M., Wyss M., Zanier, V. Europe and China in the Cold War: Exchanges Beyond the Bloc Logic and the Sino-Soviet Split (175-191). Leiden: Brill.

2. Albers, M. (2016). Britain, France, West Germany and the People's Republic of China, 1969-1982: The European Dimension of China's Great Transition. London: Palgrave Macmillan.

3. Gnoinska, M. K. (2019). Chipolbrok - Continuity in Times of Change: SinoPolish Relations during the Cold War, 1949-1969. In: Schaufelbuehl, J. M., Wyss M., Zanier, V. Europe and China in the Cold War: Exchanges Beyond the Bloc Logic and the Sino-Soviet Split (192-211). Leiden: Brill.

4. Zhang, B., Zhang, J. and Yao F. (2006). Technology Transfer from the Soviet Union to the People's Republic of China: 1949-1966. Comparative Technology Transfer and Society, 4(2), 105-167.

5. Lüthi, L. M. (2010). Sino-Soviet Relations during the Mao Years, 1949-1969. In: Bernstein, T. P. and Li H. China Learns from the Soviet Union, 1949-Present (27-59). Plymouth: Lexington Books.

6. Mehilli, E. (2017). From Stalin to Mao: Albania and the Socialist World. Ithaca and London: Cornell University Press.

7. Sanchez-Sibony, O. (2014). Red Globalization: The Political Economy of the Soviet Cold War from Stalin to Khruschev. Cambridge: Cambridge University Press.

8. Shen, Z. (2020). Conflicts of Interest and Creation of the Alliance Treaty, 1949-1950. In: Shen, Z. A Short History of Sino-Soviet Relations, 1917-1991 (123-133). Palgrave Macmillan.

9. Shen, Z. (2020). Mao, Khrushchev, and the Moscow Conference, 1957. In: Shen, Z. A Short History of Sino-Soviet Relations, 1917-1991 (189-207). Palgrave Macmillan.

10. Westad, O. A. (1998). Brothers in Arms: The Rise and Fall of the Sino-Soviet Alliance, 1945-1963. Stanford: Stanford University Press.

11. Heinzig, D. (2015). The Soviet Union and Communist China 1945-1950: The Arduous Road to the Alliance. London and New York: Routledge. 
12. Чавошки, J. (2006). Заборављена епизода: југословенско-кинески односи 1947. године. Токови истиорије, 4, 183-199.

Milan Igrutinović

\title{
LESS THAN THE SUM OF ITS PARTS: THE GLOBAL MOMENTUM OF COMMUNISM AFTER THE SECOND WORLD WAR
}

\begin{abstract}
The paper provides an overview of the relations between communist parties and states after the Second World War and at beginning of the Cold War. The author highlights the trend of integration within the two ideologically opposed blocs (capitalist/Western and communist/Eastern), focusing on the communist bloc, and shows the limitations of cooperation between parties and states and differing and opposing ambitions. The author also argues that certain bilateral issues in the relations between communist parties and states thwarted the opportunities for integration and cooperation, which prevented the global rise of the communist movement. To demonstrate this, the author draws primarily on the examples of the Chinese Communist Party (CCP) and the Communist Party of Yugoslavia and their conflict with the USSR, as well as ideological and foreign policy issues.
\end{abstract}

Keywords:

communism, People's Republic of China, USSR, Yugoslavia, Cold War. 